\title{
ERRATUM
}

\section{Clinical profile and management of craniocerebral Madurella mycetoma}

TO THE READERSHIP: While preparing the letter to the editor "Clinical profile and management of craniocerebral Madurella mycetoma" (J Neurosurg Pediatr $12: 529-531,2013$ ) for publication, an error was made that resulted in the misspelling of one author's name. "Salma M. Babikir, M.B.B.S." was incorrectly published as "Salma M. Babakir, M.B.B.S."

The authors' listing now reads:

Hүтнам K. S. Hamid, M.R.C.S.ED.

Mohamed A. Mohamed, M.B.B.S.

SAlMa M. BabikiR, M.B.B.S.

Waterford Regional Hospital

Waterford, Ireland

We apologize to the authors and readers for this typographical error. The error has been corrected online as of December 12, 2014.

Gillian Shasby

Director of Publications-Operations

Journal of Neurosurgery Publishing Group, Charlottesville, VA

\section{INCLUDE WHEN CITING}

Published online December 12, 2014; DOI: 10.3171/2014.11.PEDS13274a.

(c)AANS, 2015 